\title{
Role of Social Media Influencers in Tourism Destination Image: How Does Digital Marketing Affect Purchase Intention?
}

\author{
I Putu Gede Iwan Trisna Jaya ${ }^{1}$ and Ida Bagus Teddy Prianthara ${ }^{2}$ \\ ${ }^{1}$ Department of Management, Faculty of Economics and Business, Undiknas University, Indonesia \\ ${ }^{2}$ Department of Accounting, Faculty of Economics and Business, Undiknas University, Indonesia
}

*Email: iwantrisna@undiknas.ac.id

\begin{abstract}
This study aimed to measure the influence of social media influencers, destination image, and brand image on the purchase intention of tourists who visited the Bratan Lake, Bedugul, a major tourist attraction. The study population comprised foreign tourists; the sample size was 179. Respondents were selected using the convenience sampling technique. The data was then processed and analyzed using structural equation modeling with PLS software. The results show that social media influencers, destination image, and brand image have a positive and significant effect on purchase intention. Brand image has a higher correlation-coefficient value compared to destination image with regard to purchase intention. This indicates that the manager of a tourism destination should take into account the price paid by tourists for the attributes and the benefits they receive. The three indicators of brand image are quality, track record, and reliability, indicating that tourists will look to fulfill their previously held expectations during and after traveling.
\end{abstract}

Keywords: social media influencer, destination image, brand image, purchase intention

\section{Introduction}

The development of information technology over the internet has changed the available information related to tourism, as well as influenced the way people plan and make travel choices. Further expansion of the internet has had an impact on the development of social media websites such as blogs, forums, wikis, social networks, and YouTube on its way to becoming a medium that has gained immense popularity for use by tourists (Pan, MacLaurin, \& Crotts, 2007). Travelers post and share comments, opinions, and experiences related to their travels, including during the trip, which ultimately serves as an information source for others, in such websites.

Tourism products have intangible characteristics because the consumer cannot evaluate them without traveling. Thus, online suggestions/recommendations can be used as evidence before booking travel products and be factored into decisions, to reduce the risk involved in the process. They often also form the destination image of a tourist area for a potential tourist, affecting the purchase intention for tour packages (Jeong \& Jang, 2011). On social media, people develop a sense of community and they therefore trust comments posted online (Utz, Kerkhof, \& van den Bos, 2011). To determine the best options for travel, consumers use social media to seek out information about possible destinations, visualize images, and access postings about others' previous tourist experiences (Sicilia \& Ruiz, 2010). Consumer involvement with the internet, especially social media, has become an interesting phenomenon for researchers, particularly in the field of tourism marketing (Constantinides, 2014). Researchers and practitioners in the tourism marketing field pay great attention to how tourists are influenced by interactions with other consumers, primarily so-called social media influencers. This has become a key factor in the development of effective marketing strategies for tourist destinations and in building destination images (Ye, Law, Gu, \& Chen, 2011).

Nowadays, marketing through social media influencers is considered a form of marketing where the focus is placed on a certain individual, a so-called "microcelebrity." A marketer can identify an individual who influences potential buyers, their social media followers, then direct their marketing activity around the 
influencer's individual activities (Stephen, 2016). According to Senft (2008), an influencer is a form of microcelebrity that gathers followers on blogs or other social media through posts, in the form of textual and visual narratives from everyday life. A social media influencer, including traveling bloggers and other travel influencers, often acquire endorsement deals for certain fashion products. According to Marwick and Boyd (2011), "influencer" refers to internet users who gain "followers," or fans, on social media. There is a closer bond between the influencer and their followers, as well as a closer social distance, when compared to conventional fans, due to status (Abidin, 2015). Influencers originally surfaced and gained popularity through various blog platforms in 2005, which slowly spread to other social-media platforms, such as Facebook, Twitter, YouTube, Instagram, and Snapchat.

\subsection{Relationship Between Variables}

\subsubsection{Social- Media Influencer, Destination Image, and Brand Image}

Social media has changed the way people plan travel, including the way they buy and consume tourism products. Furthermore, it has dramatically changed the role of the middleman, which now overlaps the role of the influencer. Finally, social-media influencers are now being used as efficient marketing tools to promote and shape the destination image of a tourist destination (Kracht \& Wang, 2009). Positive online feedback, comments, or reviews from social-media influencers can improve the perception of travel products among potential users. Thus, online suggestions/comments provided by other users about online sales of tourism products enhance the brand image and have a significant effect on improving destination image and purchase intention (Ye et al., 2011).

In order to beat the competition, a marketing manager should create an online image that makes the brand stand out when compared to its competitors, thus communicating the main advantage of the service and positioning it favorably toward the target market. This destination image can directly describe the quality of the service to customers, which has a major influence on the customer's perceptions of the value and satisfaction they would receive by purchasing it. Ultimately, the destination image can affect the brand image and influence purchasing decisions, known as purchase intention (Prendergast \& Man, 2002).

The following hypotheses were generated based on the aforementioned study:

H1: Social-media influencers have a positive and significant influence on destination image.

$\mathrm{H} 2$ : Social-media influencers have a positive and significant impact on brand image.

H3: Destination image has a positive and significant impact on brand image.

\subsubsection{Social-Media Influencer, Brand Image, and Purchase Intention}

Brand image consists of the attributes and benefits associated with the brand that make it stand out as different. Thus, it is necessary to differentiate what a company offers from its competitors (Webster \& Keller, 2004). An attribute is a descriptive feature that characterizes a brand according to consumers' desires in terms of purchase or consumption, and a benefit is the personal value embedded in the consumer's image of a brand; in other words, what consumers think or feel a brand can do for them (1998). Consumers will have a greater purchase intention for a brand they are familiar with (Kamins \& Marks, 1991). Similarly, if a tourism destination has a better brand image, it will have a higher market share, coupled with better-quality evaluations than its competitors (Grewal et al., 1998). A tourist destination with a well-known brand has a higher purchase intention than a lesser known brand (Hsu, 2009).

Research conducted by Leung, Law, Hoof, and Buhalis (2013) involved the use of social media by influencers and traveler bloggers in the tourism and hospitality field. They found that consumers are generally interact with traveler social media throughout the travel process, such as during planning, consumption, and after a trip. The social-media interactions of an influencer or travel blogger in sharing information related to the characteristics of tourism services, including attractions, accessibility, amenities, packages, activities, and ancillary services, can help a company effectively reach its marketing goals (Buhalis, 2000). In influencer marketing, the individual is expected to spread the word through their personal social-media channels. Therefore, most influencer campaigns have a content component intended to form a brand image and influence the purchase intention of their followers (Tapinfluence, 2016). 
Purchase intention represents the possibility that a consumer will be planning or willing to buy a certain product or service in the future. Increased purchase intention equates to an increased likelihood of purchase (Schiffman $\&$ Kanuk, 2007). Researchers can use purchase intention as an important indicator for predicting consumer behavior. When a consumer has a strong purchase intention, it reinforces a positive brand image, thereby encouraging the consumer to actually make the purchase.

The following hypotheses were generated based on the aforementioned research:

H4: Social-media influencers have a positive and significant impact on purchase intention.

H5: Brand image has a positive and significant impact on purchase intention.

H6: Destination image has a positive and significant effect on purchase intention.

As part of this research, the proposed hypotheses can be illustrated through the framework in Figure 1.

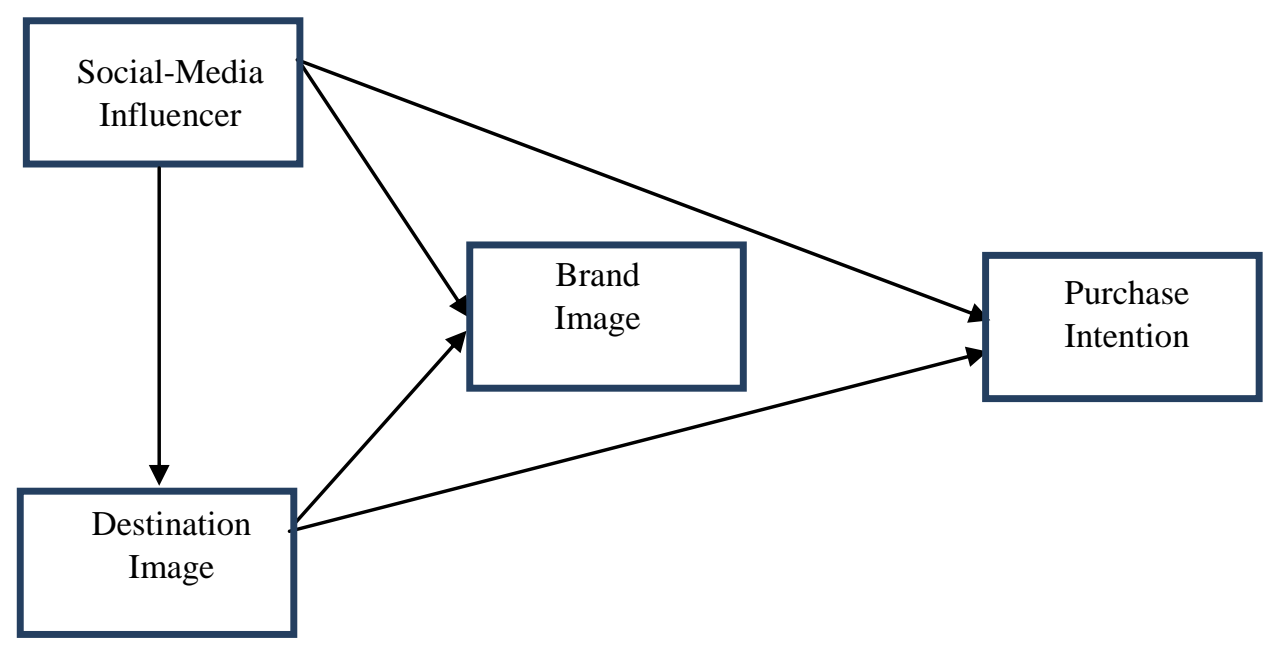

Figure 1. Structural Model

\section{Method}

\subsection{Research Design}

For this research related to tourism marketing, one of the important variables was understanding which factors affect tourists (Darnell \& Johnson, 2001). Research conducted by Chi and Qu (2008) found that destination image affects a tourist's decision-making, such as by which destination they choose to visit, their perception of the destination, and their future intentions. In addition, according to Bigne, Sanchez, and Sanchez (2001), socialmedia influencers have a positive effect on destination image, brand image, and purchase intention.

\subsection{Population and Sample}

The population for this research was visitors to Bratan Lake Bedugul, an ecotourism attraction. The convenience sampling method was used to obtain the research sample, foreign tourists who like ecotourism attractions. Of the 250 questionnaires that were distributed, 179 were returned. In this research, both quantitative and qualitative data, as well as both primary and secondary data sources were used.

\subsection{Operational Definition and Research Variables}

Since the current research relates to management, the research variable was measured directly, but through observed dimensions or indicators (Ghozali, 2001). In this research, the indicator or dimension was determined by the respondent's perception of the destination image, trip quality, value, and satisfaction, and by their behavioral intention, as obtained from the distributed questionnaire. Each of the presented variables was measured by observing the indicators presented in the questionnaire, using a Likert scale.

The preliminary study found that there were 17 indicators that have the highest validity and reliability, based on a research sample of 30 tourists:

1. The social-media-influencer variable is in five indicator questions. 
2. The destination image variable is in six indicator questions.

3. The brand image variable is in three indicator questions.

4. The purchase intention variable is in three indicator questions.

\subsection{Data-Collection Method}

The data-collection method was a questionnaire that utilized a Likert scale of 1-5. The sampling method used was a convenience technique in which the respondents were chosen based on the criterion of liking Geopark Kintamani Bangli as a tourism location (as stated in Table 1).

Table 1. Operation and Measurement of Variables

\begin{tabular}{|c|c|c|}
\hline Variable & Indicator & Source \\
\hline \multirow[t]{5}{*}{ Social-Media Influencer } & $\begin{array}{l}\text { Content of X brand's social-media influencer seems } \\
\text { interesting. }\end{array}$ & \multirow[t]{5}{*}{ Kim and Ko (2012) } \\
\hline & $\begin{array}{l}\text { X brand's social-media influencer enables information } \\
\text { sharing with others. }\end{array}$ & \\
\hline & $\begin{array}{l}\text { Conversation or an exchange of opinions with others is } \\
\text { possible through X brand's social-media influencer. }\end{array}$ & \\
\hline & $\begin{array}{l}\text { Content of X brand's social-media-influencer account } \\
\text { has the newest information. }\end{array}$ & \\
\hline & $\begin{array}{l}\text { I would like to pass on information about a destination } \\
\text { image from X brand's social-media inluencer to my } \\
\text { friends. }\end{array}$ & \\
\hline \multirow[t]{6}{*}{ Destination Image } & A lot of cultural attractions to visit & \multirow{6}{*}{$\begin{array}{l}\text { Lee, Lee, and Lee (2005) } \\
\text { Qu, Kim, and Im (2011) }\end{array}$} \\
\hline & Cultural diversity & \\
\hline & Good quality of tourism infrastructure & \\
\hline & Relaxed atmosphere & \\
\hline & Unpolluted and unspoiled environment & \\
\hline & Exotic destination & \\
\hline \multirow[t]{3}{*}{ Brand Image } & $\begin{array}{l}\text { In comparison to other products/brands, this is a high } \\
\text { quality product/brand. }\end{array}$ & \multirow[t]{3}{*}{$\begin{array}{l}\text { Davis, Golicic, } \\
\text { Marquardt (2009) }\end{array}$} \\
\hline & This product/brand has a rich history. & \\
\hline & $\begin{array}{l}\text { Customers (we) can reliably predict how this } \\
\text { product/brand will perform. }\end{array}$ & \\
\hline \multirow[t]{3}{*}{ Purchase Intention } & $\begin{array}{l}\text { I would visit this tourism destination rather than any } \\
\text { other destination. }\end{array}$ & \multirow[t]{3}{*}{ Shukla, 2010} \\
\hline & $\begin{array}{l}\text { I am willing to recommend that others visit this tourism } \\
\text { destination. }\end{array}$ & \\
\hline & I intend to revisit this tourist destination in the future. & \\
\hline
\end{tabular}

\subsection{Data Analysis Method}

The data analysis method used in this research was a structural equation model (SEM), a multivariate statistical technique combining factor and regression analyses (correlation) to examine the relationship among the variables presented in the model, either between the indicator and the construct, or between the constructs (Santoso, 2012). According to Ferdinand (Uttami, 2012), the SEM research method can evaluate an 
interdependent relationship. There are seven stages of modeling with this method: (1) developing the model based on a theory, (2) preparing the path diagram, (3) constructing the structural equation, (4) selecting the input matrix and model/estimation technique, (5) assessing the possibility of problem identification, (6) evaluating the usefulness of the criteria, and (7) interpreting and modifying the data.

\section{Results and Discussion}

\subsection{Instrument-Reliability and Validity Testing}

Reliability testing aims to determine the consistency of a measurement tool by using it to measure the same items more than twice. A measurement tool is therefore considered to be reliable when it is used several times on the same items and it consistently produces the same results (Sugiyono, 2010). In other words, a highreliability measurement tool gives reliable results. In measuring reliability level, a reliable variable is usually considered to be one that has a Cronbach's alpha value of greater than 0.6. The following table shows the reliability test result for each variable in the questionnaire. All the items presented in Table 4.1 are therefore considered to be reliable.

Table 4.1. Reliability Test Result

\begin{tabular}{ll}
\hline & Cronbach's Alpha Value \\
\hline Brand Image & 0.767 \\
\hline Destination Image & 0.858 \\
\hline Purchase Intention & 0.835 \\
\hline Social-Media Influencer & 0.837 \\
\hline \multicolumn{2}{c}{ Source: Data processed, 2018. }
\end{tabular}

Validity testing was also conducted on the varibles in the questionnaire using the Pearson method, the results of which are shown in in Table 4.2. For the social-media-influencer (X1) variable, all the relevant questionnaire items demonstrate a correlation value of greater than 0.3. Similarly, the destination image (Y1) and brand image (Y2) variables each show a correlation value of greater than 0.3 , which means that those items are also reliable. In addition, the purchase intention (Y3) variable earned a total score that is also greater than 0.3 , meaning that all those items are reliable. Thus, it can be concluded that all the indicators and research items used in this study are reliable.

Table 4.2. Validity Test Result Using Bivariate Pearson Method

\begin{tabular}{lll}
\hline Variable & \multicolumn{1}{l}{ Indicator } & Pearson Correlation \\
\hline Social-Media Influencer & $\mathrm{X} 1.1$ & $0.420^{* *}$ \\
\cline { 2 - 3 } & $\mathrm{X} 1.2$ & $0.276^{* *}$ \\
\cline { 2 - 3 } & $\mathrm{X} 1.3$ & $0.267^{* *}$ \\
\cline { 2 - 3 } & $\mathrm{X} 1.4$ & $0.344^{* *}$ \\
\cline { 2 - 3 } & $\mathrm{X} 1.5$ & $0.296^{* *}$ \\
\hline Destination Image & $\mathrm{Y} 1.1$ & $0.259^{* *}$ \\
\cline { 2 - 3 } & $\mathrm{Y} 1.2$ & $0.320^{* *}$ \\
\cline { 2 - 3 } & $\mathrm{Y} 1.3$ & $0.318^{* *}$ \\
\cline { 2 - 3 } & $\mathrm{Y} 1.4$ & $0.288^{* *}$ \\
\cline { 2 - 3 } & $\mathrm{Y} 1.5$ & $0.285^{* *}$ \\
\cline { 2 - 2 } & & $0.307^{* *}$ \\
\hline
\end{tabular}




\begin{tabular}{lll}
\hline Variable & Indicator & Pearson Correlation \\
\hline Brand Image & Y2.1 & $0.256^{* *}$ \\
\cline { 2 - 3 } & Y2.2 & $0.236^{* *}$ \\
\cline { 2 - 3 } & Y2.3 & $0.333^{* *}$ \\
\hline Purchase Intention & Y3.1 & $0.594^{* *}$ \\
\cline { 2 - 3 } & Y3.2 & $0.602^{* *}$ \\
\cline { 2 - 3 } & Y3.3 & $0.456^{* *}$ \\
\hline
\end{tabular}

\subsection{Data Analysis Method}

Source: Data processed, 2018.

The data analysis method used in this research was inferential analysis using SEM in the SmartPLS 3.0 application. There were two steps to this research: 1) evaluating the measurement model, or outer model, to examine the relationship between the indicators designed as latent variables, and 2) evaluating the structural model, or inner model, to determine the relationship between the variables in the research model.

\subsection{Measurement Model (Outer Model) Evaluation}

In evaluating the measurement model, or outer model in the research, the validity and reliability measurements of the reflexive indicators use criteria such as a) convergent validity, b) discriminant validity, and c) composite reliability, as well as Cronbach's alpha.

\subsubsection{Convergent Validity}

Convergent validity is one of the criteria used to measure the validity of reflexive indicators. Such evaluation is done by determining the outer-loading coefficient of each indicator to its latent variable. An indicator is considered valid if the outer-loading coefficient is between 0.6-0.7. In order to analyze an unclear theory such as in this research, however, it is recommended that the outer-loading coefficient be 0.5 (Lathan \& Ghozali, 2012), with the alpha-level significance being 0.05 or a t-statistic of 1.96 . It can be seen in the forthcoming Table 4.3 that all the indicators show that each variable's outer-loading value as greater than 0.6 and significant at a level of 0.05 . Thus, the all indicators are valid. It should be noted that the outerloading and coefficient methods are used in Table 4.1, whereas the bootstrapping model is used in Figure 4.2.

Table 4.3. Outer-Loading Value of Model Estimation

\begin{tabular}{llllll}
\hline & $\begin{array}{l}\text { Original } \\
\text { Sample } \\
(\mathbf{O})\end{array}$ & $\begin{array}{l}\text { Sample } \\
\text { Mean } \\
(\mathbf{M})\end{array}$ & $\begin{array}{l}\text { Standard } \\
\text { Deviation } \\
(\mathbf{S T D E V})\end{array}$ & $\begin{array}{l}\text { T-Statistic } \\
(\mid \mathbf{O} / \mathrm{STDEV})\end{array}$ & P Value \\
\hline $\mathbf{x 1 . 1}<-$ Social-Media Influencer & 0.856 & 0.855 & 0.022 & 38.311 & 0.000 \\
\hline $\mathbf{x 1 . 2}<-$ Social-Media Influencer & 0.791 & 0.787 & 0.031 & 25.277 & 0.000 \\
\hline $\mathbf{x 1 . 3}<-$ Social-Media Influencer & 0.723 & 0.720 & 0.046 & 15.829 & 0.000 \\
\hline $\mathbf{x 1 . 4}<-$ Social-Media Influencer & 0.771 & 0.769 & 0.043 & 17.887 & 0.000 \\
\hline $\mathbf{x 1 . 5}<-$ Social-Media Influencer & 0.746 & 0.745 & 0.038 & 19.790 & 0.000 \\
\hline $\mathbf{y 1 . 1}<-$ Brand Image & 0.816 & 0.815 & 0.030 & 27.166 & 0.000 \\
\hline $\mathbf{y 1 . 2}<-$ Brand Image & 0.831 & 0.828 & 0.025 & 32.590 & 0.000 \\
\hline $\mathbf{y 1 . 3}<-$ Brand Image & 0.830 & 0.829 & 0.029 & 29.098 & 0.000 \\
\hline $\mathbf{y 2 . 1}<-$ Destination Image & 0.820 & 0.819 & 0.040 & 20.329 & 0.000 \\
\hline $\mathbf{y 2 . 2}<-$ Destination Image & 0.689 & 0.686 & 0.042 & 16.253 & 0.000 \\
\hline y2.3 <- Destination Image & 0.794 & 0.792 & 0.030 & 26.151 & 0.000 \\
\hline
\end{tabular}




\begin{tabular}{llllll}
\hline & $\begin{array}{l}\text { Original } \\
\text { Sample } \\
(\mathbf{O})\end{array}$ & $\begin{array}{l}\text { Sample } \\
\text { Mean } \\
(\mathbf{M})\end{array}$ & $\begin{array}{l}\text { Standard } \\
\text { Deviation } \\
(\mathbf{S T D E V})\end{array}$ & $\begin{array}{l}\text { T-Statistic } \\
(\mid \mathbf{O} / \mathrm{STDEV})\end{array}$ & P Value \\
\hline $\mathbf{y 2 . 4}<-$ Destination Image & 0.739 & 0.734 & 0.039 & 19.073 & 0.000 \\
\hline $\mathbf{y 2 . 5}<-$ Destination Image & 0.754 & 0.753 & 0.040 & 18.643 & 0.000 \\
\hline $\mathbf{y 2 . 6}<-$ Destination Image & 0.786 & 0.786 & 0.037 & 21.296 & 0.000 \\
\hline $\mathbf{y 3 . 1}<-$ Purchase Intention & 0.881 & 0.881 & 0.018 & 48.907 & 0.000 \\
\hline $\mathbf{y 3 . 2}<-$ Purchase Intention & 0.887 & 0.886 & 0.020 & 44.709 & 0.000 \\
\hline $\mathbf{y 3 . 3}<-$ Purchase Intention & 0.833 & 0.831 & 0.031 & 26.529 & 0.000 \\
\hline
\end{tabular}

Source: Data processed, 2018.

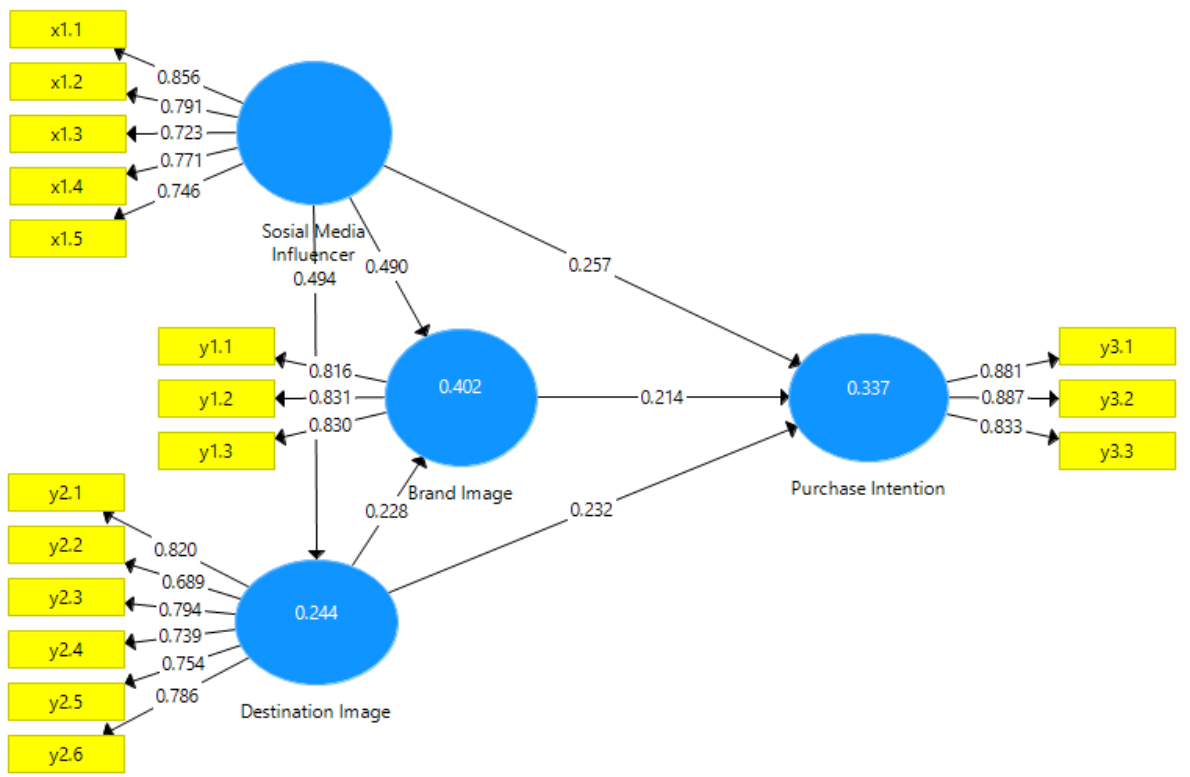

Figure 4.1. Outer-Loading and Coefficient Path 


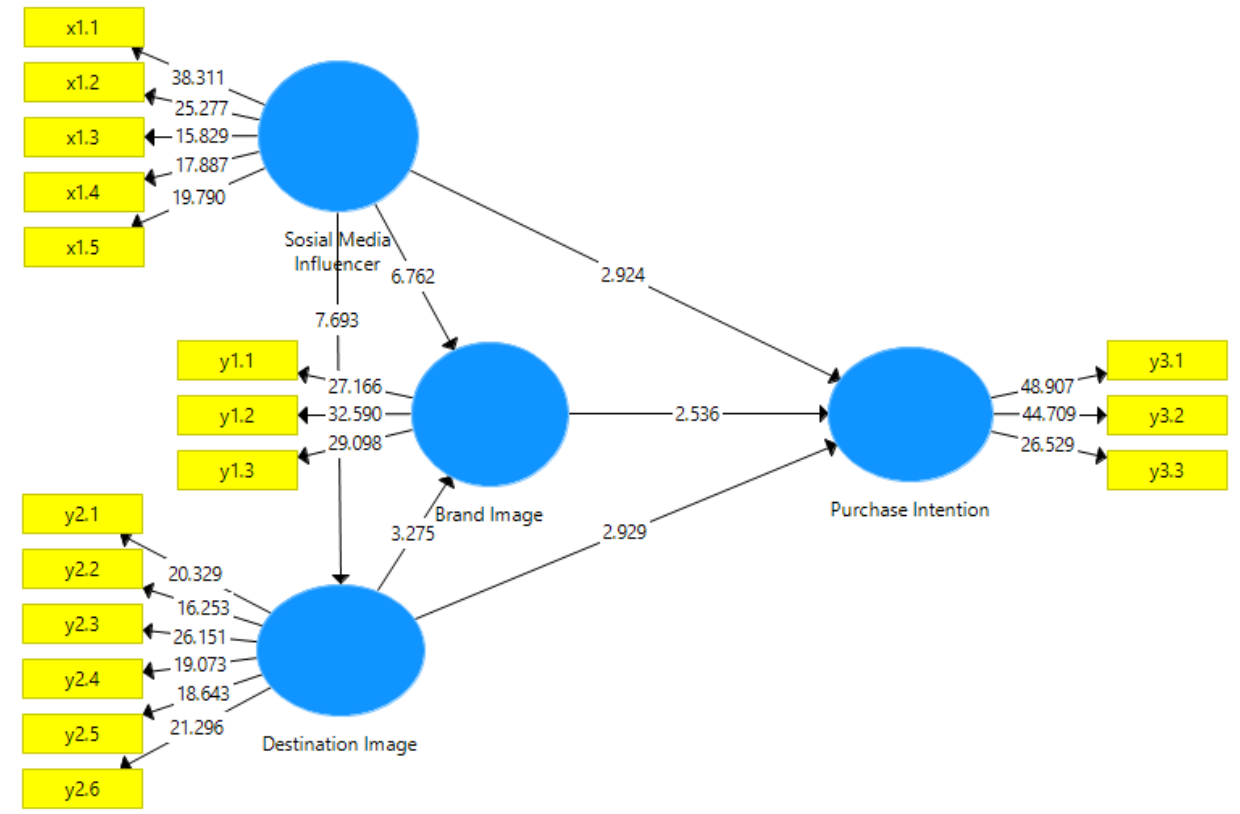

Figure 4.2. Bootstrapping Model

\subsubsection{Discriminant Validity}

Discriminant validity is another indicator validity measurement for latent variables. Discriminant validity is measured by comparing the average variance extracted (AVE) root coefficient ( $\mathrm{AVE}$ ) of each variable to the correlation value of the variables in the model. A variable is considered valid if the AVE root is greater than the correlation value between the variables in the research model (Lathan \& Ghozali, 2012) and if the AVE is greater than 0.5 .

Table 4.4 Discriminant Validity

\begin{tabular}{ccc}
\hline & $\begin{array}{c}\text { Average Variance } \\
\text { Extracted (AVE) }\end{array}$ & $\sqrt{ }($ AVE) \\
\hline Brand Image & 0.682 & 0.825 \\
\hline Destination Image & 0.585 & 0.764 \\
\hline Purchase Intention & 0.752 & 0.867 \\
\hline Social-Media Influencer & 0.606 & 0.778 \\
\hline
\end{tabular}

Source: Data processed, 2018.

The preceding Table 4.4 shows that a measurement tool can be considered reliable if the composite reliability and Cronbach's alpha, which measure the reliability between the indicator blocks in a research model, are greater than 0.7 .

Table 4.5. Composite Reliability and Cronbach's Alpha Tests

\begin{tabular}{ccc}
\hline & $\begin{array}{c}\text { Cronbach's } \\
\text { Alpha }\end{array}$ & $\begin{array}{c}\text { Composite } \\
\text { Reliability }\end{array}$ \\
\hline Brand Image & 0.767 & 0.865 \\
\hline
\end{tabular}




\begin{tabular}{ccc}
\hline Destination Image & 0.858 & 0.894 \\
\hline Purchase Intention & 0.835 & 0.901 \\
\hline Social-Media Influencer & 0.837 & 0.885 \\
\hline
\end{tabular}

Source: Data processed, 2018.

The preceding Table 4.5 shows that the value of composite reliability and Cronbach's alpha of all the variables have a value greater than 0.7 . Thus, they are considered to be reliable, based on composite reliability criteria.

\subsection{Structural Model Evaluation (Inner Model)}

In evaluating the structural/ inner model, a researcher evaluates the accuracy of the model for the entire research project, formed by several variables as well as their indicators. Several approaches are used in this evaluation, including: a) R-Square $\left(\mathrm{R}^{2}\right)$, b) Q-Square Predictive Relevance $\left(\mathrm{Q}^{2}\right)$, and c) Goodness of Fit.

Table 4.6. Evaluation of Structural/Inner Model

\begin{tabular}{lll}
\hline & $\mathbf{R}^{\mathbf{2}}$ & $\mathbf{R}^{\mathbf{2}}$ Adjusted \\
\hline Brand Image & 0.402 & 0.395 \\
\hline Destination Image & 0.244 & 0.240 \\
\hline Purchase Intention & 0.337 & 0.325 \\
\hline
\end{tabular}

Source: Data processed, 2018.

The preceding Table 4.6 shows that the $\mathrm{R}^{2}$ of brand image is 0.402 , of destination image is 0.244 , and of purchase intention is 0.337 . According to the Chin criteria (Lathan \& Ghozali, 2012), it can be concluded that the predictors of latent variables have an intermediate effect on the structural model.

\subsection{Hypothesis Testing}

Path analysis and hypothesis testing of the current research predicts that Ho will be rejected, or that the sig. value will be $<0.05$ (or that the t-statistic value will be $>1.96$ if it is tested against a significant level being 0.05). Table 4.7 shows that the $\mathrm{P}$ value for each indicator is $<0.05$ and that the $\mathrm{t}$-statistic value is $>1.96$. Therefore, Ho is rejected for each indicator, and H1 is accepted. It can be concluded that the path analysis and statistical testing show that the model has a positive effect and is significant.

Table 4.7. Path Analysis and Statistical Testing

\begin{tabular}{llllll}
\hline & $\begin{array}{l}\text { Original } \\
\text { Sample } \\
(\mathbf{O})\end{array}$ & $\begin{array}{l}\text { Sample } \\
\text { Mean } \\
(\mathbf{M})\end{array}$ & $\begin{array}{l}\text { Standard } \\
\text { Deviation } \\
(\mathbf{S T D E V})\end{array}$ & $\begin{array}{l}\text { T Statistics } \\
(\mathbf{O O} / \mathbf{S T D E V} \mid)\end{array}$ & P Value \\
\hline Brand Image -> Purchase Intention & 0.214 & 0.216 & 0.084 & 2.536 & 0.012 \\
\hline Destination Image -> Brand Image & 0.228 & 0.234 & 0.070 & 3.275 & 0.001 \\
\hline Destination Image -> Purchase Intention & 0.232 & 0.230 & 0.079 & 2.929 & 0.004 \\
\hline Social-Media Influencer -> Brand Image & 0.490 & 0.484 & 0.072 & 6.762 & 0.000 \\
\hline Social-Media Influencer -> Destination Image & 0.494 & 0.499 & 0.064 & 7.693 & 0.000 \\
\hline $\begin{array}{l}\text { Social-Media Influencer -> Purchase } \\
\text { Intention }\end{array}$ & 0.257 & 0.258 & 0.088 & 2.924 & 0.004 \\
\hline
\end{tabular}


Table 4.7 shows that all the relationships among the variables are significant, meaning that all of the research objectives have been answered. The perceptions of social-media influencers, assesed with five indicators, have a positive and significant influence on destination image, brand image, and purchase intention, as seen in probability values of 0.000 and 0.004 (less than 0.05) and t counts of 7.693, 6.762, and 2.924 (greater than a statistical value of 1.96), with correlation coefficients of $0.494,0.490$, and 0.257 . This indicates that the better the information that is disseminated about a tourist destination by an influencer, the better the destination image and brand image of the location. The results of this study are in accordance with research conducted by Chen and Kim et. al (2017).

Based on the same table, the destination image is also shown to have a positive and significant effect on the brand image and purchase intention, with correlation coefficients of 0.288 and 0.232 . This is in accordance with the research conducted by Bruwer (2017). The brand image and purchase intention of travelers will be stronger if supported by destination image.

The practical implications of this research are that, in order to increase the purchase intention level related to tourism product, it is suggested that the management of a tourist destination try to form a positive brand image of it through social-media influencers (Wu et al. 2011). According to this research, positive image is formed by highlighting interesting cultural attractions, owned infrastructure, a pleasant/pollution-free environment, and exotic imagery of the tourist destination. Based on the correlation-coefficient values of each indicator, it can be seen that Bedugul Lake excels with the pleasant environment indicator, which is a primary indicator for forming a positive destination image.

Thus, managers should strive to work with social-media influencers to form a positive image of their tourism business, which will be accompanied by a positive effect on destination image and brand image. Intentions to visit and to share the benefits received are indicators of the purchase intention variable, which will also increase the number of visitors every year (Qu et al., 2011)

\section{Suggestion}

Based on the research results, social-media influencers are one form of promotional media that must be built positively to improve the destination image and brand image of a tourist destination. Managers of tourist destinations should pay attention to a pleasant and pollution-free environment, especially if they want their business to be an established ecotourism destination. In addition to these two indicators, based on the results relating to the tourism destination, management should also pay attention to promoting interesting tourist attractions that can entice tourists to visit. Furthermore, a good tourism-support infrastructure should also be organized. The whole package makes a tourist destination be seen as unique and exotic in the eyes of tourists.

Additionally, management should consider several indicators related to quality, track record, and reliability of the destination, so that the attributes and benefits of a region be consistent with tourists' expectations. This should be done in order to improve the brand image of a tourist destination and provide a positive experience. Finally, by leveraging destination image and brand image, social-media influencers can have a positive and significant influence on purchase intention. Forming a positive image and creating a high perceived value will increase tourist satisfaction. In so doing, return visits and word-of-mouth promotion by tourists will increase.

\section{Conclusion}

Based on the research results, it can be concluded that: Destination image and perceived value have a positive and significant influence on the level of customer satisfaction and behavioral intention. Geopark Kintamani is a tourist destination with ecotourism market segmentation, along with appreciation from UNESCO related to the Geopark of the world. It appears that the destination image variable should have two indicators, namely pleasant environment and pollution-free environment. As an ecotourism destination, the desired image has been successfully perceived by tourists. The perceived value variable shows the economic-value indicator, with the dominant value of money compared to the other two indicators. This shows that the tourists feel the benefits of traveling and are satisfied with the amount of money paid. 
The level of customer satisfaction reflected in the brand image indicators and variables plays a very important role in increasing purchase intention, especially a tourist's desire to make a return visit and engage in word-ofmouth promotion to other potential tourists.

\section{References}

Abidin, C. (2015). Communicative intimacies: Influencers and perceived interconnectedness. Ada: Journal of Gender, New Media, \& Technology, 8. Retrieved from https://adanewmedia.org/2015/11/issue8-abidin/

Abidin, C. (2016). Visibility labour: Engaging with Influencers' fashion brands and \#OOTD advertorial campaigns on Instagram. Media International Australia, 161(1). https://doi.org/10.1177/1329878X16665177

Bigne, J. E., Sanchez, M. I., \& Sanchez, J. (2001). Tourism image, evaluation variables and after purchase behaviour: Inter-relationship. Tourism Management, 22, 607-616.

Buhalis, D. (2000) "Marketing the Competitive Destination of the Future", Tourism Management, Vol. 21 No. 1, pp. 97-116.

Chi, C. G-Q, \& Qu, H. (2007). Examining the structural relationships of destination image, tourist satisfaction and destination loyalty: An integrated approach. Tourism Management, 29, 624-636.

Darnell, A. C., \& Johnson, P. S. (2001). Repeat visits to attractions: A preliminary economic analysis. Tourism Management, 22(2), 119-126.

Davis, D. F., Golicic, S. L., \& Marquardt, A. (2009), "Measuring brand equity for logistics services", International Journal of Logistics Management, Vol. 20 No. 2, pp. 201-12.

Constantinides, E. (2014). Foundations of Social Media Marketing. Procedia-Social and Behavioral Sciences, 148 ,

40-57. https://doi.org/10.1016/j.sbspro.2014.07.016

Qu, H., Kim, L. H., \& Im, H. H. (2011). A model of destination branding: Integrating the concepts of the branding and destination image. Tourism Management, 32, 465-476.

Hsu, Y. Y. (2000). The impact of brand awareness, reference price, product knowledge and product characteristics on brand evaluation and consumers' purchase intention (Unpublished master thesis), National Cheng Kung University, Taiwan.

Jeong, E., \& Jang, S. (2011). Restaurant experiences triggering positive electronic word-of-mouth (eWOM) motivations. International Journal of Hospitality Management, 30(2011), 356-66.

Kim, A. J., \& Ko, E. (2012). Do social media marketing activities enhance customer equity? An empirical study of luxury fashion brand. Journal of Business Research, 65, 1480-1486.

Kracht, J., \& Wang, Y. (2009). Examining the tourism distribution channel: evolution and transformation. International Journal of Contemporary Hospitality Management, 22(5), 736-757.

Lee, C., Lee, Y., \& Lee, B. (2005). Korea's destination image formed by the 2002 world cup. Annals of Tourism Research, 32(4), 839-858.

Leung, D., Law, R., Hoof, H. van, \& Buhalis, D. (2013). Social media in tourism and hospitality: A literature review. Journal of Travel \& Tourism Marketing, 30(1-2), 3-22.

Marwick, A. E, \& Boyd, D. (2011). To see and be seen: celebrity practice on Twitter. Convergence, 17(2), 139158.

Pan, B., MacLaurin, T., \& Crotts, J. C. (2007). Travel blogs and their implications for destination marketing. Journal of Travel Research, 46(1), 35-45.

Prendergast, G., \& Man, H. W. (2002). The influence of store image on store loyalty in Hong Kong's quick service restaurant industry. Journal of Foodservice Business Research, 5(1), 45-59.

Santoso, S. (2011). Structural Equation Modelling (SEM). Jakarta: PT Elex Media Komputindo.

Schiffman, L.G., \& Kanuk, L. L. (2007). Consumer Behavior ( $9^{\text {th }}$ ed.). Upper Saddle River, NJ: Prentice Hall.

Senft, T. M. (2008). Camgirls: Celebrity and Community in the Age of Social Networks. New York, NY: Peter Lang.

Shukla, P. (2010). Impact of interpersonal influences, brand origin and brand image on luxury purchase intentions: measuring interfunctional interactions and a cross-national comparison. Journal of World Business, 46(2), 242-52.

Sicilia, M., \& Ruiz, S. (2010). The effect of web-based information availability on consumers' processing and attitudes. Journal of Interactive Marketing, 24, 31-41.

Stephen, A. (2016). The role of digital and social media marketing in consumer behavior. Current Opinion in Psychology, 10, 17-21. 
Utz, S., Kerkhof, P., \& van den Bos, J. (2011). Consumers rule: how consumer reviews influence perceived trustworthiness of online store. Electronic Commerce and Applications (in press).

Webster, F.E., \& Keller, K.L. (2004). A roadmap for branding in industrial markets. Brand Management, 11(5), 388-402.

Ye, Q., Law, R., Gu, B. \& Chen, W. (2011). The influence of user-generated content on traveller behavior: An empirical investigation on the effects of e-word-of mouth to hotel online booking. Computers in Human Behavior, 27(2), 634-9. 